\title{
Balanced discussion of second-generation antihistamines' data
}

This article was published in the following Dove Press journal:

Therapeutics and Clinical Risk Management

24 November 2016

Number of times this article has been viewed

\author{
Rossen Boev' \\ Jürgen WG Bentz ${ }^{2}$ \\ 'UCB Pharma, Bulle, Switzerland; \\ ${ }^{2}$ UCB Pharma, Brussels, Belgium
}

Correspondence: Rossen Boev UCB Farchim SA, Chemin De Croix Blanche 10, 1630 Bulle, Switzerland Email rossen.boev@ucb.com

\section{Dear editor}

It is with interest that we read the paper "Treatment of allergic rhinitis and urticaria: a review of the newest antihistamine drug bilastine" by Wang et al, ${ }^{1}$ in which the authors provide insights into the burden of allergic diseases in the Asia-Pacific region. Unfortunately, we found that the review provides some unsubstantiated information, incorrect statements, and/or data inconsistencies as listed below.

The abstract states that bilastine "has very low potential for drug-drug interactions"; however, the drug label lists interactions with ketoconazole, erythromycin, diltiazem, and other intestinal efflux transporters, leading to 2-3-fold increases in drug maximum serum concentration and area under the curve. ${ }^{2}$ Also, food interactions decrease bilastine's bioavailability by $30 \%$, and the label recommendation is that it is taken 1 hour before or 2 hours after intake of food or fruit juice. ${ }^{2}$

Table 2 presents a comparison between widely used antihistamines; however, the +++ score for bilastine's H1-selectivity is not substantiated by the provided reference. ${ }^{2}$ Also, the highest Allergic rhinitis and its impact on asthma (ARIA) ${ }^{3}$ score attributed to bilastine in Table 2 is in contrast to the information provided in Table 1; ie, bilastine does not have higher potency or efficacy than other antihistamines (demonstrated by several studies ${ }^{4-8}$ ); has clinically relevant interactions with food; ${ }^{2}$ has the same indications and is effective on the same symptoms as other antihistamines; ${ }^{2}$ has only one pediatric study $;{ }^{9}$ and its side effect profile ${ }^{2}$ and pharmacodynamic properties are similar to other antihistamines. ${ }^{2}$ Many papers have reported that it has efficacy and safety similar to cetirizine, ${ }^{4,7,8}$ desloratadine, ${ }^{5}$ fexofenadine,${ }^{8}$ and levocetirizine. ${ }^{6}$

Table 2 contains incorrect information about the age groups of the pediatric indications for cetirizine and levocetirizine, both of which are approved by the US Food and Drug Administration for use in children as young as 6 months of age. ${ }^{10,11}$ Also, Table 2 inaccurately states that bilastine has no contraindications; according to the product label, ${ }^{2}$ "hypersensitivity to the active substance or to any of the excipients [...]" is a contraindication.

The section "Bilastine efficacy" states that "the bilastine clinical trial program was designed before the publication of the 2001 ARIA guidelines, so the patient inclusion criteria were based on the former classification of seasonal and perennial allergic rhinitis"; however, this seems to be in contrast to the information on www.ClinicalTrials.gov, where the oldest bilastine study has a start date of April 2003; ${ }^{12}$ and the other bilastine studies appear with start dates of 2004 through 2016.

A 12-month open-label safety analysis ${ }^{7}$ was described by the authors as "the longest analysis to date with any antihistamine"; however, safety analyses from 
double-blind randomized trials with cetirizine, ${ }^{13}$ loratadine, ${ }^{14}$ and levocetirizine ${ }^{15}$ over periods of $12-18$ months of treatment have already been published.

The section "No QTc prolongation" states that "to date, bilastine is the only commercially available antihistamine that has been tested using the stringent $\mathrm{ICH}$ E/14 criteria for effects on QT interval". This is incorrect as a publication in 2007 presented data from an ICH E-14 QT study with levocetirizine. ${ }^{16}$

The section "Lack of sedation" is misleading, since the bilastine product label ${ }^{2}$ lists somnolence as a "common" adverse event (ie, occurring in 1\%-10\% of patients), which is supported by data from several clinical trials reporting somnolence rates with bilastine of $5.8 \%,{ }^{6} 3.9 \%,{ }^{5} 3.7 \%$, ${ }^{7}$ and $1.8 \%{ }^{4}$

Figure 9 incorrectly presents that updosing with bilastine (80 $\mathrm{mg}$ ) appears to have 2 to 3 times as many responders as those treated with desloratadine $20 \mathrm{mg}$ or levocetirizine $20 \mathrm{mg}$. These data come from two clinical trials ${ }^{17,18}$ with completely different designs, and therefore direct comparison between them is inappropriate. The bilastine data come from a provocation test in subjects without symptoms at the time of study recruitment, whereas the levocetirizine and desloratadine data come from a real clinical trial with difficult-to-treat urticaria patients. Also, the original paper reported 12 patients ( $\sim 30 \%)$ as responders (symptom-free) on levocetirizine $20 \mathrm{mg}$ and 1 responder $(<3 \%)$ on desloratadine $20 \mathrm{mg}$. In addition, Figure 9 uses another review article ${ }^{19}$ as a reference, instead of the primary publications. ${ }^{17,18}$

As there is an unmet need in the management of allergic rhinitis in the Asia-Pacific region, we welcome novel treatment options. However, based on the available data, there is no evidence to suggest that bilastine provides superior clinical efficacy to other commonly used second-generation antihistamines. ${ }^{4-8}$

\section{Disclosure}

Jürgen WG Bentz and Rossen Boev are employees of UCB Pharma, the manufacturer of levocetirizine and cetirizine. The authors report no other conflicts of interest in this communication.

\section{References}

1. Wang XY, Lim-Jurado M, Prepageran N, Tantilipikorn P, Wang de Y. Treatment of allergic rhinitis and urticaria: a review of the newest antihistamine drug bilastine. Ther Clin Risk Manag. 2016;12:585-597.
2. Product SPCs. Available from: http://www.mhra.gov.uk/spc-pil/index. htm; http://www.mhra.gov.uk/home/groups/spcpil/documents/spcpil/ con1470373127139.pdf. Accessed September 28, 2016.

3. Bousquet J, Van Cauwenberge P, Khaltaev N; Aria Workshop Group; World Health Organization. Allergic rhinitis and its impact on asthma. J Allergy Clin Immunol. 2001;108(5 Supp1):S147-S334.

4. Kuna P, Bachert C, Nowacki Z, et al. Efficacy and safety of bilastine $20 \mathrm{mg}$ compared with cetirizine $10 \mathrm{mg}$ and placebo for the symptomatic treatment of seasonal allergic rhinitis: a randomized, double-blind, parallel-group study. Clin Exp Allergy. 2009;39(9):1338-1347.

5. Bachert C, Kuna P, Sanquer F, et al. Comparison of the efficacy and safety of bilastine $20 \mathrm{mg}$ vs desloratadine $5 \mathrm{mg}$ in seasonal allergic rhinitis patients. Allergy. 2009;64(1):158-165.

6. Zuberbier T, Oanta A, Bogacka E, et al. Comparison of the efficacy and safety of bilastine $20 \mathrm{mg}$ vs levocetirizine $5 \mathrm{mg}$ for the treatment of chronic idiopathic urticaria: a multi-centre, double-blind, randomized, placebo-controlled study. Allergy. 2010;65(4):516-528.

7. Sastre J, Mullol J, Valero A, Valiente R; Bilastine Study Group. Efficacy and safety of bilastine $20 \mathrm{mg}$ compared with cetirizine $10 \mathrm{mg}$ and placebo in the treatment of perennial allergic rhinitis. Curr Med Res Opin. 2012;28(1):121-130.

8. Horak F, Zieglmayer P, Zieglmayer R, Lemell P. The effects of bilastine compared with cetirizine, fexofenadine, and placebo on allergen-induced nasal and ocular symptoms in patients exposed to aeroallergen in the Vienna Challenge Chamber. Inflamm Res. 2010;59(5):391-398.

9. Novak Z, Yanez A, Kiss I, et al. Safety and tolerability of bilastine $10 \mathrm{mg}$ administered for 12 weeks in children with allergic diseases. Pediatr Allergy Immunol. 2016;27(5):493-498.

10. Zyrtec ${ }^{\circledR}$ USPI. Available from: http://www.fda.gov/ohrms/dockets/ AC/03/briefing/3999B1_23_Zyrtec.pdf. Accessed September 28, 2016.

11. Xyzal ${ }^{\circledR}$ USPI. Available from: http://www.fda.gov/downloads/ AdvisoryCommittees/CommitteesMeetingMaterials/PediatricAdvisory Committee/UCM235280.pdf. Accessed September 28, 2016.

12. A Phase III Efficacy Study of the Symptomatic Treatment of Seasonal Allergic Rhinitis with Bilastine. Available from: https://clinicaltrials. gov/ct2/show/NCT01108783?term=bilastine $\&$ rank=13. Accessed September 28, 2016.

13. Simons FE. Prospective, long-term safety evaluation of the H1-receptor antagonist cetirizine in very young children with atopic dermatitis. ETAC Study Group. Early Treatment of the Atopic Child. J Allergy Clin Immunol. 1999;104(2 Pt 1):433-440.

14. Grimfeld A, Holgate ST, Canonica GW, et al. Prophylactic management of children at risk for recurrent upper respiratory infections: the Preventia I Study. Clin Exp Allergy. 2004;34(11):1665-1672.

15. Simons FE; Early Prevention of Asthma in Atopic Children (EPAAC) Study Group. Safety of levocetirizine treatment in young atopic children: an 18-month study. Pediatr Allergy Immunol. 2007;18(6):535-542.

16. Hulhoven R, Rosillon D, Letiexhe M, et al. Levocetirizine does not prolong the QT/QTc interval in healthy subjects: results from a thorough QT study. Eur J Clin Pharmacol. 2007;63(11):1011-1017.

17. Staevska M, Popov TA, Kralimarkova T, et al. The effectiveness of levocetirizine and desloratadine in up to 4 times conventional doses in difficultto-treat urticaria. J Allergy Clin Immunol. 2010;125(3):676-682.

18. Krause K, Spohr A, Zuberbier T, Church MK, Maurer M. Up-dosing with bilastine results in improved effectiveness in cold contact urticaria. Allergy. 2013;68(7):921-928.

19. Sánchez-Borges M, Ansotegui I, Jimenez JM, Rojo MI, Serrano C, Yanez A. Comparative efficacy of non-sedating antihistamine updosing in patients with chronic urticaria. World Allergy Organ J. 2014; 7(1):33. 


\section{Authors' reply}

Xue Yan Wang'

Margaret Lim-Jurado²

Narayanan Prepageran ${ }^{3}$

Pongsakorn Tantilipikorn ${ }^{4}$

De Yun Wang ${ }^{5}$

'Department of Allergy, Beijing Shijitan Hospital, Capital Medical University, Beijing, People's Republic of China; ${ }^{2}$ St Luke's Medical Center, Quezon City, Manila, Philippines; ${ }^{3}$ Department of Otorhinolaryngology, Head \& Neck Surgery, University Malaya Faculty of Medicine, Kuala Lumpur, Malaysia; ${ }^{4}$ Rhinology and Allergy Division, Department of Otorhinolaryngology, Faculty of Medicine Siriraj Hospital, Mahidol University, Bangkok, Thailand; ${ }^{5}$ Department of Otolaryngology, Yong Loo Lin School of Medicine, National University of Singapore, Singapore

Correspondence: De Yun Wang

Department of Otolaryngology, Yong Loo Lin School of Medicine,

National University of Singapore, IE Kent Ridge Road, Singapore I 19228

Tel +6567725373

Fax +6567753820

Email entwdy@nus.edu.sg

\section{Dear editor}

Thank you for the opportunity to review the content of the letter by Bentz and Boev in response to our article entitled "Treatment of allergic rhinitis and urticaria: a review of the newest antihistamine drug bilastine". ${ }^{1}$ Below is a point-bypoint response to the letter.

The abstract states that bilastine "has very low potential for drug-drug interactions"; however, the drug label lists interactions with ketoconazole, erythromycin, diltiazem, and other intestinal efflux transporters, leading to 2- to 3-fold increases in drug $C_{\max }$ and area under the curve. Also, food interactions decrease bilastine's bioavailability by $30 \%$, and the label recommendation is that it is taken 1 hour before or 2 hours after intake of food or fruit juice.

Response: The complete sentence in the abstract says,

This agent does not interact with the cytochrome P450 enzyme system and does not undergo significant metabolism in humans, suggesting that it has a very low potential for drug-drug interactions.

As the authors note, there is some potential for interactions with intestinal efflux transporters. It would have been more accurate to have stated in the abstract that bilastine has a very low potential for hepatic drug-drug interactions. Thank you for pointing this out. On the other hand, taken in the context of the whole sentence discussing hepatic enzyme systems and metabolism, we believe that the nature of the drug-drug interactions was implicit.
Table 2 presents a comparison between widely used antihistamines, however, the +1+ score for bilastine's H1-selectivity is not substantiated by the provided reference. Also, the highest Allergic rhinitis and its impact on asthma (ARIA) score attributed to bilastine in Table 2 is in contrast to the information provided in Table 1; ie, bilastine does not have higher potency or efficacy than other antihistamines (demonstrated by several studies); has clinically relevant interactions with food; has the same indications and is effective on the same symptoms as other antihistamines; has only one pediatric study; and its side effect profile and pharmacodynamic properties are similar to other antihistamines. Many papers have reported that it has efficacy and safety similar to cetirizine, desloratadine, fexofenadine, and levocetirizine.

Response: Table 2 is primarily based on the Summary of Product Characteristics for each agent. We believe that the high score for bilastine can be justified based on the number of favorable ARIA characteristics it shows, including the $\mathrm{H}_{1}$-selectivity score, which can be justified based on published data. The other characteristics that Bentz and Boev point out (same indications as other antihistamines, lack of pediatric indication, food interaction) are all listed in Table 2 for bilastine. Bentz and Boev report:

its side effect profile and pharmacodynamic properties are similar to other antihistamines. Many papers have reported that it has efficacy and safety similar to cetirizine, desloratadine, fexofenadine, and levocetirizine.

Table 2 makes no claims about the comparative efficacy or side effect profile of the antihistamines. Rather it describes their approved indications and pharmacological profile. An important differentiating feature of bilastine is the lack of a need for dosage adjustment in patients with renal or hepatic failure, which contributes to its high score. ${ }^{2}$

Table 2 contains incorrect information about the age groups of the pediatric indications for cetirizine and levocetirizine, both of which are approved by the US Food and Drug Administration for use in children as young as 6 months of age. ${ }^{10,11}$ Also, Table 2 inaccurately states that bilastine has no contraindications; according to the product label, "hypersensitivity to the active substance or to any of the excipients $[\ldots]$ " is a contraindication.

Response: Table 2 is based on the European labels for the antihistamines. We believe that the pediatric indications listed in the table are accurate according to the reference cited. With regard to the contraindications, all agents are contraindicated 
in people with sensitivity to the ingredients, and so this was not specified in the table as it applies to all antihistamines (and indeed all drugs). You will note that the same principle has been applied to describing the contraindications for desloratadine, fexofenadine, and loratadine.

Section "Bilastine efficacy" states that "the bilastine clinical trial program was designed before the publication of the 2001 ARIA guidelines, so the patient inclusion criteria were based on the former classification of seasonal and perennial allergic rhinitis"; however, this seems to be in contrast to the information on www.ClinicalTrials.gov, where the oldest bilastine study has a start date of April 2003; and the other bilastine studies appear with start dates of 2004 through 2016.

Response: The sentence is not inaccurate. Planning for the clinical trial program began well in advance of the initiation of the first trial in April 2003. At the time that the clinical trial program was planned, the 2001 ARIA guidelines had not yet been published, and the patient inclusion criteria were based on the former classification of seasonal and perennial allergic rhinitis.

A 12-month open-label safety analysis was described by the authors as "the longest analysis to date with any antihistamine"; however, safety analyses from doubleblind randomized trials with cetirizine, loratadine, and levocetirizine over periods of 12-18 months of treatment have already been published.

Response: We apologize for this error and would welcome publication of an erratum clarifying this issue.

The section "No QTc prolongation" states that "to date, bilastine is the only commercially available antihistamine that has been tested using the stringent ICH E-14 criteria for effects on QT interval". This is incorrect as a publication in 2007 presented data from an ICH E-14 QT study with levocetirizine.

Response: We apologize for this error and would welcome publication of an erratum clarifying this issue.

The section title "Lack of sedation" is misleading, since the bilastine product label ${ }^{2}$ lists somnolence as a "common" adverse event (ie, occurring in 1\%-10\% of patients), which is supported by data from several clinical trials reporting somnolence rates with bilastine of $5.8 \%, 3.9 \%$, $3.7 \%$, and $1.8 \%$.
Response: This section of the manuscript describes several studies demonstrating a lack of effect on objective measures of psychomotor performance with bilastine. Although Bentz and Boev are right to point out that somnolence has occurred in between $1 \%$ and $10 \%$ of patients receiving bilastine in clinical trials, the rate of somnolence with bilastine is no higher than with placebo. ${ }^{2}$ Therefore, in our opinion, the heading is not inaccurate.

Figure 9 incorrectly presents that updosing with bilastine ( $80 \mathrm{mg}$ ) appears to have 2 to 3 times as many responders as those treated with desloratadine $20 \mathrm{mg}$ or levocetirizine $20 \mathrm{mg}$. These data come from two clinical trials with completely different designs, and therefore direct comparison between them is inappropriate. The bilastine data come from a provocation test in subjects without symptoms at the time of study recruitment, whereas the levocetirizine and desloratadine data come from a real clinical trial with difficult-to-treat urticaria patients. Also, the original paper reported 12 patients $(\sim 30 \%)$ as responders (symptomfree) on levocetirizine $20 \mathrm{mg}$ and 1 responder $(<3 \%)$ on desloratadine $20 \mathrm{mg}$. In addition, Figure 9 uses another review article as a reference, instead of the primary publications.

Response: Figure 9 in our article presents data from an indirect comparison of data from several clinical trials, which was written by Sánchez-Borges et $\mathrm{al}^{3}$ and published in World Allergy Journal. It is described thus in our paper:

A comparison of clinical trial data for second-generation antihistamines in chronic urticaria suggests that this bilastine dosage is significantly more effective than supratherapeutic dosages of desloratadine and levocetirizine (Figure 9).

The data presented in Figure 9 are as they appear in the indirect comparison paper by Sánchez-Borges et al. ${ }^{3}$ The Sánchez-Borges et $\mathrm{al}^{3}$ paper is described as a review by Bentz and Boev in this letter, yet it is labeled by the journal that published it as "original research", presumably because they applied comparative analysis to previously published data. Although we could have sourced the original papers on which the indirect comparison was based, as suggested by Bentz and Boev in this letter, to verify the findings of the Sánchez-Borges et al analysis, we had no reason to suspect that the Sánchez-Borges et al analysis misrepresented the original findings, and our description of the analysis (as a comparison of clinical trial data) does not overstate the Sánchez-Borges et al conclusions. In our opinion, this 
criticism of the interpretation of these data should be leveled at the authors of the indirect comparison (Sánchez-Borges et $\mathrm{al}^{3}$ ), and as yet we were unable to find any correspondence indicating that this has taken place.

\section{Disclosure}

The authors report no conflicts of interest in this communication.

\section{References}

1. Wang XY, Lim-Jurado M, Prepageran N, Tantilipikorn P, Wang de Y. Treatment of allergic rhinitis and urticaria: a review of the newest antihistamine drug bilastine. Ther Clin Risk Manag. 2016;12:585-597.

2. Bilastine SPC. Available from: http://www.mhra.gov.uk/spc-pil/index. htm; http://www.mhra.gov.uk/home/groups/spcpil/documents/spcpil/ con1470373127139.pdf). Accessed September 28, 2016.

3. Sánchez-Borges M, Ansotegui I, Jimenez JM, Rojo MI, Serrano C, Yanez A. Comparative efficacy of non-sedating antihistamine updosing in patients with chronic urticaria. World Allergy Organ J. 2014;7(1):33.

Dove Medical Press encourages responsible, free and frank academic debate. The content of the Therapeutics and Clinical Risk Management 'letters to the editor' section does not necessarily represent the views of Dove Medical Press, its officers, agents, employees, related entities or the Therapeutics and Clinical Risk Management editors. While all reasonable steps have been taken to confirm the content of each letter, Dove Medical Press accepts no liability in respect of the content of any letter, nor is it responsible for the content and accuracy of any letter to the editor.

\section{Publish your work in this journal}

Therapeutics and Clinical Risk Management is an international, peerreviewed journal of clinical therapeutics and risk management, focusing on concise rapid reporting of clinical studies in all therapeutic areas, outcomes, safety, and programs for the effective, safe, and sustained use of medicines. This journal is indexed on PubMed Central, CAS,
EMBase, Scopus and the Elsevier Bibliographic databases. The manuscript management system is completely online and includes a very quick and fair peer-review system, which is all easy to use. Visit http://www.dovepress.com/testimonials.php to read real quotes from published authors.

Submit your manuscript here: http://www.dovepress.com/therapeutics-and-clinical-risk-management-journal 